\title{
Peregrinação e alegoria: uma leitura do Compêndio Narrativo do Peregrino da América
}

\author{
Jean Luiz Neves Abreu
}

Em 1728 era publicado em Lisboa o Compêndio narrativo do peregrino da América em que se tratam de vários discursos espirituais e morais, com muitas advertências e documentos contra os abusos que se acham introduzidos pela malícia diabólica no Estado do Brasil. ${ }^{1}$ De autoria do religioso Nuno Marques Pereira, natural de Cairú, na Bahia ${ }^{2}$, a obra é a narrativa de uma viagem que faz um suposto "peregrino" da Bahia de Todos os Santos à Capitania das Minas. Além de tratar dos costumes religiosos do Estado do Brasil, a obra, conforme indica o título, tratava de esmiuçar a presença do diabo no cotidiano dos colonos, inserindo-se na tradição de demonização da América presente nas cartas jesuíticas e em tratados morais. ${ }^{3}$

Embora a obra de Nuno Marques Pereira não tenha alçado a mesma representatividade que teve a de outros religiosos, considerado muitas vezes como mais um tratado moralista, na edição de 1939 do Compêndio Narrativo... Varnhagen enfatizava, ainda que com certo tom laudatório, o potencial da narrativa como fonte documental para estudos acerca da sociedade colonial:

... é sem dúvida que este livro, dentre os da antiga literatura brasileira, é um dos que se recomendam, não só pela moralidade das doutrinas, como pelo estilo e correção da linguagem, pelas descriçôes que dá, já das paisagens, já dos usos e abusos do Brasil, e, finalmente, pela instrução do autor, que fora ainda contemporâneo do padre Vieira, cuja locução por vezes tanto imita que muitos de seus períodos podiam passar como da pena do mesmo jesuíta. ${ }^{4}$ 
A recomendação de Varnhagen foi acolhida principalmente por certa historiografia preocupada em estudar as mentalidades e comportamentos dos colonos na América Portuguesa. De fato, aos interessados em buscar aí informações acerca do cotidiano, das festas, dos rituais, dos hábitos alimentares, dos costumes dos negros e do gentio, entre outros temas "picarescos", encontrará um vasto painel da sociedade do Setecentos. ${ }^{5}$ Outra perspectiva de abordagem dos estudos históricos toma a obra em questão para enfocar o esforço moralizador empreendido pela igreja da contra-reforma ou para exame de práticas da religiosidade - feitiçaria, calundus etc que se afastavam da religião oficial no Brasil do século XVIII. ${ }^{6}$

O objetivo do presente artigo é outro: propõe mostrar como Nuno Marques Pereira utiliza recursos da linguagem disponíveis na tradição para compor sua análise do estado dos costumes no Brasil. Neste sentido, propóe-se uma abordagem da obra de Nuno Marques Pereira não como fonte que informa acerca da "realidade", mas como "texto". Ao se analisar o Compêndio narrativo do peregrino da América..., enquanto "texto" procura afirmar que "não se pode ler literatura convenientemente como documentação conteudística da realidade", conforme propõe Alcir Pécora ${ }^{7}$. Procura-se, portanto, apropriando-se dos procedimentos desse autor, "localizar os meios discursivos disponíveis na tradição" e o "ajuste de aplicação de tais meios".

Em outros termos, empreende-se aqui um esforço de compreender como o autor do Compêndio narrativo... estabelece um ajuste entre os recursos retóricos e aos fins a que se destinam, bem como trata também de mostrar como a construção do texto se dá de forma dinâmica, por meio de um diálogo entre elementos discursivos disponíveis na tradição e análise dos costumes e das práticas religiosas que observa na sociedade da América Portuguesa no século XVIII, os quais atuam como elementos decisivos na construção do texto.

Este procedimento tem por objeto a obra como um todo. Na medida em que os capítulos tanto do primeiro quanto do segundo volume do Compêndio Narrativo... são independentes, tratando cada um de assuntos diversos, a opção por determinadas partes da obra levou em conta a seleção de temas que evidenciassem os procedimentos formais de construção do texto e as tópicas que atendessem aos objetivos da obra: descrição dos costumes condenados e prédicas com finalidades moralizadoras. 


\section{1}

Ao se pensar a adequação dos recursos disponíveis na tradição, a primeira questão que preocupa o autor do Compêndio narrativo do peregrino da América é a do encaminhamento de procedimentos da leitura de sua obra por uma comunidade de leitores. Já de início, no prólogo ao leitor do $2^{\circ}$ volume, adverte ao suposto leitor:

E quando suceda tomares por divertimento leres este livro, usa dele, como costumam fazer os mineiros. Os mineiros, que vão tirar ouro e diamantes nos rios das Minas, metem a bateia na água, e o que trazem nela é a areia e cascalho; porém, nem de uma coisa, nem de outra fazem caso, e só o que procuram é verem se acham algum grão de ouro, ou lasca de diamante, e o demais lançam fora. ${ }^{9}$

Por meio de um artifício alegórico, Nuno Marques Pereira compara a areia e o cascalho às palavras inúteis, e o grão de areia e a lasca de diamante aos ditos dos santos padres e palavras da Sagrada Escritura. Os leitores devem, pois, se comportar como os mineiros que separam a areia do cascalho, separando as histórias tão repetidas das palavras dos padres e da Sagrada Escritura. A passagem acima evidencia a intencionalidade de adequação do discurso ao leitor. Daí a importância de utilizar exemplos extraídos de uma prática reconhecida tal qual era a mineração no século XVIII.

Não obstante parecer que o "peregrino" narrador desdenhe das histórias, elas cumprem seu papel no texto: "Uso das presentes moralidades e histórias para melhor te persuadir deleitando-se o gosto, e entertendo-te à vontade", afirma o peregrino. Mas, para além de uma estratégia de persuasão, trata-se aí também da adoção de um estilo apropriado ao leitor pretendido:

Não notes o estilo humilde de que uso nesta escrita, porque além de não ser o meu intento escrever só para particulares, fugi de subir muito por me não precipitar; porque sempre ouvi dizer que quem mais alto sobe, maior queda dá, e por isso me quis acomodar às regras do histórico, e deixar as de panegirista. ${ }^{10}$

O estilo humilde parece ter o peregrino acolhido do padre Antônio Vieira, considerado "Príncipe dos pregadores, sol dos oradores e oráculo do púlpito" ${ }^{11}$. Relembre-se aqui o Sermão da Sexagésima, pregado em Lis- 
boa em 1655, em que Vieira atacava o "estilo tão dificultoso, e tão afetado". ${ }^{12}$ As aproximaçôes entre as obras de Vieira e de Nuno Marques Pereira não param por aí. Certos trechos da obra de Nuno Marques Pereira remetem diretamente a excertos da obra de Vieira. Veja-se, por exemplo, a acusação que o "peregrino" faz aos pregadores no púlpito que agem como representantes de comédias: "Porque sempre me pareceu mal, ver alguns pregadores no púlpito, feitos representantes de comédias, e tão presumidos de retóricos, que não há quem os entenda." ${ }^{13}$ A citação guarda aproximação inequívoca com o trecho do Sermão da Sexagésima, em que o padre Vieira ataca a afetação culta dos pregadores:

Uma das felicidades que se contava entre as do tempo presente, era acabarem-se as comédias em Portugal; mas não foi assim. Não se acabaram, mudaram-se; passaram-se do teatro ao púlpito. Não cuideis que encareço em chamar comédia a muitas pregações das que hoje se usam. ${ }^{14}$

Tanto um quanto outro se preocupava, portanto, com a falta de decoro nas artes. Para Nuno Marques Pereira, as

artes não podem deslustrar nem desfavorecer o juízo dos homens, quando delas usam licitamente. A moderação com que se usa nas artes é que lhe dá mais ou menos preço e estimação, e assim sem razão se nota a um poeta de o ser, quando só deve ser louvado, e aplaudido. ${ }^{15}$

A questão do preceito retórico do decoro se relaciona diretamente com a adequação da arte de pregar. Sobre este aspecto, o que Alcir Pécora afirma para Vieira pode ser adequado também para Nuno Marques Pereira:

Trata-se de repor o preceito retórico do decoro, da conveniência de pessoa lugar e tempo segundo o gênero, de maneira que sua aplicação correta impeça que se perca a eficácia desejada, vale dizer, impeça que o sermão frutifique, que é o que necessariamente ocorre quando se deixa de observar a investidura humilde do pregador, cuja verossimilhança está assentada sobre o efeito da 'naturalidade' da invenção discursiva. ${ }^{16}$

Tais digressões em torno do estilo e da moderação não estão dissociadas no século XVIII, ainda que isso não seja exposto explicitamente, de um certo combate travado nas letras portuguesas contra o ornamento excessivo da linguagem, seu caráter obscuro e hiperbólico que predominava no 
"cultismo" gongórico. À época defendia-se a adoção do "estilo simples" que valorizava a clareza do pensamento; o discurso espontâneo e de simples entendimento. ${ }^{17}$ No caso de Nuno Marques Pereira, moderação e adequação da linguagem ainda deveriam vir acompanhados de uma condenação aos assuntos indignos ligados às sátiras:

Com que, sendo como é esta arte, por tantos títulos digna de ser estimada, é para sentir a multidão de poetas, que tão mal usam dela com assuntos profanos tão mal soantes, como indignos de se poderem proferir entre católicos, e outros prezando-se de satirizar a se próximo com infâmias e injúrias no crédito e honra, sem se envergonharem de deslustrar uma tão famosa arte por modo tão indigno de se praticar entre homens, que presumem ter entendimento. $^{18}$

A arte poética assume aqui matéria de moralização e é ocasião para expressar os efeitos nefastos que pode advir da sátira. Entre os exemplos que cita Nuno Marques Pereira com o intuito de proscrever a sátira se destaca o caso de Gregório de Mattos, "que fazendo uns versos satíricos a certa personagem, foi desterrado da pátria, e fora dela acabou miseravelmente, sem mais glória, que a de ser conhecido por poeta satírico..." ${ }^{19}$

Expostas as regras para a leitura da obra; as justificativas sobre a arte de narrar-pregar, Nuno Marques Pereira passa a acessar procedimentos disponíveis na tradição a fim de cativar os fiéis para o caminho da fé e da salvação. Aí as histórias e moralidades que visam entreter o leitor assumem uma dimensão maior pois, conforme já foi afirmado, deve o leitor pretendido separar o ouro das palavras sagradas do cascalho das histórias repetidas.

\section{2}

Dos recursos disponíveis na tradição, o procedimento retórico da alegoria é um dos mais acessados pelo autor do Compêndio narrativo do peregrino da América... sendo a obra incorporada à tradição da literatura alegórica produzida no período colonial. ${ }^{20} \mathrm{~A}$ própria idéia de peregrinação assume dimensão alegórica: "Se repararmos que coisa é a vida de um homem neste mundo, acharemos que não é mais que uma mera peregrinação: que vão caminhando com toda a pressa para a eternidade, desde o inferior ao superior... ${ }^{21}$ 
A mensagem é clara e também o esquema adotado para figuração do discurso: o homem na terra é um peregrino que busca a salvação na eternidade, a sua vida é uma passagem tal qual a do viajante que um dia chegará ao fim de sua jornada. A base alegórica da peregrinação do Compêndio narrativo tem, entre outras referências, São Paulo: "falando com homens, [diz São Paulo] que são todos peregrinos, e que não têm aqui cidade permanente, e própria: e que vão caminhando e buscando-a, que é sem dúvida a Glória." ${ }^{22}$

Procedimento construtivo de ornamento do discurso constituído pela retórica antiga, a alegoria foi, desde a Idade Média, utilizada pelos teólogos como forma de interpretação. ${ }^{23}$ Fiel a essa tradição, Nuno Marques Pereira extrai da bíblia e dos autores da antiguidade cristã suas principais construçōes alegóricas. ${ }^{24}$ Utiliza-se também de "lugares" comuns extraídos do acervo de topoi da Antiguidade reapropriados no século XVIII pelo barroco. Um desses "lugares" mais freqüentados pela literatura eclesiástica, desde a Idade Média até o alvorecer da era romântica, é justamente a instabilidade da vida, a fugacidade, a efemeridade dos bens terrenos. ${ }^{25}$ Tais idéias são potencializadas por símbolos e emblemas indicadores da passagem do tempo, topos ligado à cultura do barroco. ${ }^{26}$

Oh caduca beleza! Oh falsa vaidade! Como te considero tão depressa arruinada! Ah infeliz! Quem te dissera, há menos de uma hora, que toda esta locução se havia de ver em silêncio triste! E que todo este garbo e bizarria tão depressa havia de desaparecer como uma exalação, que corre; uma seta veloz; uma ave que voa; um peregrino que passa; uma nau que navega; uma ampola de água; uma nuvem que se desfaz; uma flor que cai, e um vento que desaparece! ${ }^{27}$

Além da fugacidade do tempo, outro "lugar" em que o autor busca referências é a natureza. Importa comentar que Nuno Marques Pereira incorpora aqui a tendência em vestir a natureza com a roupagem edênica, procedimento comum entre os primeiros cronistas e religiosos ao se descrever as terras do Brasil. ${ }^{28}$

Deus, por sua divina providência, fecundou esta dilatada região da América, com tantos, e tão infinitos meios de se poderem sustentar seus habitadores de verdes e frondosos arvoredos, com tanta variedade de flo- 
res, frutos, legumes, campos e multidão de animais, aves, e rios, imensidade de peixes e mariscos, fontes e lagoas, além de outros muitos e grandes haveres de prata e de ouro, pedras mui preciosas, e quantidade de âmbar, que muitas vezes se acham pelas praias desta América. ${ }^{29}$

O quadro temático da natureza fértil reflete as potencialidades da terra capaz de ser habitada por oferecer meios de "sustentar seus habitadores", além de cumpir as finalidades exploratórias pelos "grandes haveres de prata e ouro" que aqui se encontram. Entretanto, tais potencialidades oferecidas pela terra se chocam com os maus costumes praticados no Estado do Brasil, principalmente pelo gentio. Estes são vistos descritos "homens soberbos, teimosos, e não querem conhecer o poder de Deus, caindo em vários e infinitos pecados de idolatria, superstiçôes e feitiçarias" ${ }^{30} \mathrm{e}$ " só depois de muita doutrina, que recebem dos operários do Santo Evangelho (...) é que se desviam, e deixam de muitos erros e abusos, que tinham tido entre si”. ${ }^{31}$ Fertilidade da terra, maus costumes e potencialidades cristianizadoras do gentio: observa-se aí a repetição de tópicas que foram recorrentes nas cartas jesuíticas e que mostram a referência de Nuno Marques Pereira a quadros temáticos pré-existentes. ${ }^{32}$

É essa mesma natureza fértil que será alegorizada para fins de conversão

Há uns pássaros no Brasil, a quem chamam andorinhas dos mangues, por andarem em bandos, porém, são muito maiores e gostosas, que as outras, que andam pelas casas, e igrejas; costumam estes pássaros pernoitar nas árvores altas dos mangues junto aos rios. Os caçadores, que disto sabem, as andam vigiando embarcando as canoas; quando as vêem tomar pouso em cima de algum mangue, deixam anoitecer e sobem pela árvore com um facho aceso na mão esquerda, e no mesmo braço levam um saco, ou samburá, dependurado; e chegando onde estão dormindo as aves, lhes põem o dedo debaixo do bico, ou boca, e com o polegar lhe apertam a cabeça, de sorte que logo as deixam mortas, e as vão recolhendo no saco, ou samburá [...]; porém, se sucede gritar ou piar alguma, todas se levantam voando e deixam só ao caçador trepado no mangue. ${ }^{33}$

O "peregrino" explica que as aves são as criaturas racionais e o caçador é o demônio. A luz do facho representa os deleites do mundo e o samburá a sepultura. Aquele pássaro que grita representa os pregadores apostólicos que nos advertem para acordar do sono do pecado. $\mathrm{O}$ uso ale- 
górico da natureza serve a propósitos diversos. Em outro excerto Nuno Marques Pereira se utiliza de exemplos extraídos da natureza para explicar por que é necessário padecer trabalhos e enfermidades nos corpos:

Isto que vemos nos corpos se experimenta nas criaturas irracionais, por conveniência da saúde corporal quando se fazem enfermos; os pássaros há tempo em que largam as penas, para depois se refazerem de novos penachos; as cobras largam a pele, o marisco as cascas, para de novo se refazerem as forças [...] As parreiras da Europa é necessário podá-las, para darem uvas; as roseiras feri-las para darem rosas. ${ }^{34}$

Como se vê, a alegoria aqui não deve ser reduzida a simples ornatus do discurso, ou seja, tomada como simples procedimento construtivo tal como pressupóe a retórica antiga. Ela toma aqui a dimensão de exemplo, própria da "alegoria dos teólogos" constituída na Idade Média e retomada pelo Barroco. ${ }^{35}$

De exemplos alegóricos o autor do Compêndio narrativo passa a exemplos propriamente ditos de onde se extraem moralidades. Estes se prestam a duas finalidades: almejam fornecer modelos de conduta e advertir sobre comportamentos inadequados. No primeiro caso, destacam-se os exemplos extraídos da vida dos santos e das sagradas escrituras. Em torno do tema dos meios de se alcançar a salvação, Nuno Marques Pereira comenta a respeito da virtude de sofrer com paciência as misérias desta vida citando o episódio bíblico de Jô:

Corrobora-se mais esta virtude com aquela admirável lição que nos deu Jô, como tão experimentado nela, quando disse (cap.14, v. 1) Homo natus de muliere, brevi vivens tempore, repletur multis miseris: $\mathrm{O}$ homem nascido da mulher, vivendo tempo limitado, está cheio de misérias: para nos dar a entender o como está a nossa natureza sujeita a tantas misérias e trabalhos para termos paciência. ${ }^{36}$

Ainda sobre o tema do sofrimento físico afirma que o homem deve mirar no exemplo dos santos:

Outros espelhos mais manuais são os santos, que, sendo de carne e osso, como nós [...] sofreram com admirável paciência suas dores e aflições muito maiores que as nossas, por amor de Cristo. ${ }^{37}$ 
Quando o "peregrino" deseja advertir acerca dos comportamentos inadequados se utiliza da narração de histórias que noticiam os abusos cometidos no Estado do Brasil. É o caso do relato extraído do capítulo em que Nuno Marques Pereira em que adverte o quanto são nocivos e prejudiciais ao bem da "República" as comédias, bailes, toques de viola e músicas desonestas:

Nas Minas do ouro de São Paulo, em uma vila chamada Ribeirão do Carmo, assistia um homem por nome Francisco Leitão Pereira, o qual era em extremo inclinado a fazer comédias, e nelas entrar, a representá-las. Sucedeu que estando em certa ocasião ensaiando a uns comediantes, lhe deu uma dor excessiva, que em breves horas acabou a vida. ${ }^{38}$

Claro está que os exemplos não só traduzem o estado das coisas, como também expõem os castigos exemplares que estão expostos aqueles que praticam tais atos. Aí se tem a descrição dos pecados e desvios morais de que padece a população no Estado do Brasil, que são adequados aos fins propostos para a conversão. A exemplos daquilo que teria observado, o autor acrescenta outros se adequando às regras do discurso histórico. É o caso da passagem em que faz alusão a uma festa romana, que de profana se fez sacra, representando a vitória do Cristianismo sobre o paganismo.

Em Roma houve muitos abusos na gentilidade, como era a festa das candeias, com que iam festejar aquela deusa, rodeando os muros das cidades. Houve um sumo pontífice que fez mudar do profano ao divino, fazendo solenizar a festa de Nossa Senhora da Purificação, a 2 de fevereiro, com o título das Candeias. ${ }^{39}$

Aos exemplos extraídos daquilo que presenciou e da história, o "peregrino" acrescenta outros daquilo que viu. Pode-se tomar aqui o trecho em que Nuno Marques Pereira descreve as Minas do Ouro que representam os sete pecados mortais:

Vi pelas ruas destas vilas, a uns homens pendenciando com outros, e vi a outros homens arrastando sacos e canastras pelas ruas e estradas. Vi a outros correndo atrás de mulheres, e as mulheres correndo atrás de homens. Vi a outros como loucos, saltando e mordendo a si próprios. Vi a outros assentados em mesas de muitos manjares, com as bocas e as mãos cheias, e outros com frascos e garrafas postos à boca. Via a outros arrepelando-se e puxando 
pelos cabelos e barbas. Vi a outros em varandas, e outros debaixo de sombras de árvores dormindo ao sono solto. ${ }^{40}$

A narração tem aspecto verossímil, entretanto, não se tem aí a descrição da realidade, mas dos pecados que o "peregrino" vê nas Minas do Ouro. Neste sentido, ver assume o sentido de interpretação da realidade, portanto, sentido alegórico. ${ }^{41} \mathrm{O}$ exemplo funciona aqui como alegoria dos pecados que o "peregrino" vê nas Minas do Ouro:

E suposto, que estes sete pecados mortais, e todos os mais gêneros e espécies de culpas se acham nas criaturas por todo o mundo, sabei que nas Minas do Ouro estão como em seu centro, e se vêem mais claramente pela razão da ambição das muitas riquezas em que se ocupam, e estão vivendo tão descuidados da lembrança das suas salvações... ${ }^{42}$

Ainda que colhidos ao acaso, os excertos citados demonstram que os exemplos, antes de serem testemunhos inequívocos da realidade, funcionam como modelos de conduta e como estereótipo dos pecados vivenciados pelos colonos no Brasil, cuja verossimilhança é garantida pelo intermédios da narrativa de histórias, analisadas, por sua vez, pelo óculo da teologia moral. De acordo com o que se observa nas construções alegóricas e nos exemplos, a necessidade de atingir ao leitor pretendido requer a mistura de diversos planos do discurso presente no texto, onde se observa uma fala coloquial com exemplos populares e históricos correndo em paralelo com referências e citações eruditas. ${ }^{43}$

\section{3}

A questão da citação na obra de Nuno Marques Pereira merece ser analisada de forma mais detida. Seu uso atende aqui ao princípio da retórica clássica segundo o qual o discurso deve ser referendado pela autoridade. As citações sofrem uma adequação de acordo com os temas que estão sendo expostos, sendo necessárias para referendar as prédicas de Nuno Marques Pereira. Por exemplo, para falar do inferno a fonte é a Sagrada Escritura:

E se quereis saber com mais certeza que coisa é o inferno? Perguntai a Jô $(10,22)$. Ele vos dirá que é uma região cheia de trevas hediondas, onde não 
há ordem alguma, mas um horror intolerável, e uma confusão eterna. Salomão (Proverb. 9.18) vos certificará que é um abismo tão profundo que dele não saberá sair que uma vez nele cair. Isaías (24.22) vos explicará que é uma prisão cheia de um fogo abrasador. ${ }^{44}$

Em outras passagens são os primeiros padres da Igreja que são citados para conferir autoridade ao "peregrino". Justificando a finalidade de homem passar por provações e enfermidades para alcançar a salvação, pedia que se ouvisse "as sentenças dos Santos Padres", que serviriam de "receita e lenitivo" para o homem:

Diz São João Chrisóstomo, que o melhor é fazer da necessidade virtude e padecer com merecimento o que se havia de padecer sem ele [...] São Basílio nas suas regras diz: que não ponha um enfermo toda sua confiança no médico e nas medicinas, atribuindo a isto a causa de sarar ou não, mas que ponha toda sua confiança em Deus, o qual às vezes quer dar-lhe saúde nessas medicinas e outras vezes não. ${ }^{45}$

Outras fontes para Nuno Marques Pereira são os moralistas e pregadores. Além da já referida influência de Vieira, reporta a outros a influência de seu estilo:

Dom João de Palafox, Bispo de Osma, no seu livro Pastor de la noche buena. $\mathrm{O}$ padre Alexandre de Gusmão, no seu livro Peregrino predestinado. $\mathrm{O}$ mesmo estilo o praticou Tristão Barbosa de Carvalho no seu livro Peregrinação cristã. Frei Heitor Pinto, no seu livro intitulado Imagem da vida cristã. $\mathrm{O}$ padre João da Fonseca, da Companhia de Jesus, o mesmo estilo no seu livro intitulado Satisfação de agravos, e confusão de vingativos.

Além desses autores, dos quais colhe referências ao longo da obra, Nuno Marques Pereira extrai moralidades da obra de Manuel Bernardes. É o caso da história de um certo Frei Antônio de Cristo, judeu sentenciado pelo Santo Ofício que se converteu à lei de Cristo do livro do Padre Bernardes Estímulo prático para seguir o bem, e fugir do mal. ${ }^{46}$

As referências à Sagrada Escritura, aos santos padres e a outras obras moralistas - que pertencem a um repertório comum em que bebem grande parte dos autores eclesiásticos — articulam-se, por sua vez, com a citação de autores como Aristóteles, Platão, Sêneca, Hipócrates, entre outros. Na medida em que a apropriação dos autores de antigüidade latina e grega se 
prestam a fins doutrinários, o autor procurava ajustar o código da ciência às finalidades moralizantes de sua obra. Tomemos um exemplo ao acaso em que o autor faz referência a Aristóteles:

Diz Aristóteles com outros que procedem os cometas dos vapores da terra, e que estes se condensam com o calor do sol, e destes se fazem os cometas[...] Diz ele que assim como os humores nocivos no corpo humano concorrem e se ajuntam a um lugar, onde geram tumor, ou apostema, assim as exalações sublunares, viscosas, secas e crassas, ou pingues se ajuntam na parte, onde se ascende o cometa, e de seus influxos perniciosos nascem os seus ruins efeitos.$^{47}$

A citação dos pensadores da Antiguidade clássica, a exemplo de Sócrates, Aristóteles e Platão, quando não são diretamente citados, são incorporados ao pensamento de autores que se referem a eles. Por exemplo, por intermédio da obra de Frei Heitor Pinto, cita Platão, e o mesmo faz com Aristóteles, citado através de Tomás de Aquino e de autores jesuítas, como João da Fonseca. ${ }^{48}$

Galeno, Hipócrates e Avicena eram, por sua vez, referências para o aconselhamento do "peregrino" sobre os cuidados com corpo para a conservação da saúde. Por exemplo, era fundamentado na teoria galênica e hipocrática que Nuno Marques Pereira mencionava os atributos positivos do vinho. Não se pode negar

as grandes utilidades do vinho tomados em boa ordem: porque sustenta e repara as forças perdidas mais depressa que o comer, como diz aquele aforismo de Hipócrates: facilius est refici potu, quam cibo: faz bom cozimento para a nutrição e provoca o suor e a urina: é sumo remédio para os velhos, conforme o que diz Galeno: quodo animi mores capit. ${ }^{49}$

Entretanto, caso o homem o beba, em excesso pode causar danos ao corpo: "Priva-o tanto dos sentidos, que o torna pior que um bruto, pelos efeitos que lhe faz obrar." ${ }^{0}$

A relação estabelecida com os textos citados revela o papel da experiência na obra de Nuno Marques Pereira que, em diversas passagens, contrapõem-se ao conhecimento estabelecido. Por exemplo, colocava-se o "peregrino" contra os aforismos e sentenças dos médicos que diziam que o sêmen retido causava enfermidades e mortes, "porque a experiência ad 
oculum está nos mostrando o contrário." ${ }^{1}$ A concepção do conhecimento no Compêndio narrativo... partia, portanto, da análise de casos específicos da realidade, de onde eram extraídos significados morais e analisados à luz do conhecimento teológico. Diversas citações e referências funcionam como força de autoridade, desde que não fossem contrários às finalidades mais amplas da obra.

\section{4}

Os dispositivos da alegoria, exemplo e citação são articulados, no texto, ao diálogo. Ao se tratar da "forma dialógica" presente no Compêndio narrativo... estamos diante de um gênero dinâmico que se adaptou a várias obras e circunstâncias. O diálogo remonta a uma tradição que nasceu com a poesia épica e cuja autonomia foi alcançada com Platão. Utilizado pelos padres da Igreja e presente nos escritos retóricos da Idade Média, o gênero será retomado pelos humanistas do Renascimento sendo recorrente nas obras de Maquiavel e Castiglione, dentre outros. ${ }^{52}$ Filiando-se à longa tradição do diálogo, Nuno Marques Pereira busca suas referências em diversas obras, moralistas ou não, em que o gênero está presente, entre as quais se pode citar Diálogos (1589), de Frei Amador Arrais, e Corte na Aldeia (1619), de Francisco Rodrigues Lobo. ${ }^{53}$

É necessário precisar melhor os fins que atendem o uso do diálogo por Nuno Marques Pereira, já que sua utilização funciona como um fio condutor da narrativa, estando presente em todos os capítulos. Tratam-se de diálogos que envolvem personagens alegóricas e fictícias. É o caso, por exemplo, dos capítulos dedicados à poesia e à música em que o "peregrino" estabelece respectivamente diálogos com as mestras da poesia, da música e da filosofia, as quais funcionam como princípio de autoridade. Nesses capítulos se trata, por um lado, de se estabelecer um debate sobre o melhor uso das referidas artes, como já se sublinhou aqui em relação à poesia. Por outro lado, procura-se subordinar essas artes a onipotência divina. É o que se observa na ocasião em que o "peregrino" anuncia à " mestra da filosofia" que" esta ciência foi dada e ensinada por Deus, desde o princípio do mundo a Adão e alguns de seus descendentes". ${ }^{54}$

Outro diálogo estabelecido ao longo da obra é com a figura alegórica do ancião. $\mathrm{O}$ ancião representa a experiência e assume o papel de um 
interlocutor em posição superior: "E assim conhecei agora que sou o tempo bem empregado. De mim têm falado vários autores sagrados e profanos." ${ }^{5} \mathrm{O}$ papel do ancião é o de escutar, contrapor e, principalmente, dar conselhos, como aquele em que adverte ao "peregrino" que "fujais de que vos enganem os três inimigos da alma, que são: mundo, diabo e carne" ${ }^{56}$ Além do caráter de confronto ou, em alguns casos, de cooperação, o diálogo pressupõe também uma encenação tal como aquela que se estabelece entre dois religiosos, um mestre e outro, discípulo: "Chegaram logo dois religiosos, e ambos de missa, um mais velho, que era mestre, e o de menos idade, o discípulo. Subiram um e outro a seu púlpito...". ${ }^{57}$

Ao fundamentar seus diálogos entre personagens com distintas posições intelectuais, Nuno Marques Pereira lança mão dos elementos tradicionais do gênero. ${ }^{58}$ Conforme afirma Alcir Pécora,

o diálogo pode ser retoricamente definido como gênero que compõe diferentes discursos a partir do relato de uma cena dramática mínima que pressupóe a presença simultânea de personagens com distintas posições intelectuais, convivendo em uma determinada situação que exige a prática racional. ${ }^{59}$

Bem se observa que o diálogo não é usado de forma aleatória no Compêndio narrativo do peregrino da América. O gênero possui considerável força persuasiva na medida em que lança mão de um registro retórico informal e da fala coloquial; elementos que expostos de forma argumentativa procuram orientar ao leitor a formação de um acordo sobre a melhor forma de ação. ${ }^{60}$ O diálogo é, portanto, o gênero eleito por Nuno Marques Pereira para atingir o fim desejado da conversão dos fiéis. Daí não ser aleatória a escolha do tema dos quatro novíssimos do homem - a morte, o Juízo, inferno e paraíso - para finalizar o segundo volume da obra a partir do diálogo entre o mestre e o discípulo. Os diálogos assumem aí função persuasiva e de esclarecer aos fiéis sobre o que são os novíssimos do homem. Cita-se aqui, apenas para exemplificar, passagem alusiva ao inferno em que o discípulo pede ao mestre que este lhe explique o que vem a ser o inferno:

D. ... isto suposto, senhor reverendo padre mestre, tomara agora que me fizesseis o favor de continuar com a vossa santa doutrina acerca do terceiro novíssimo do homem, que é o inferno, ainda que não pode haver coisa mais terrível e espantosa para uma criatura vivente e racional, como seja o de tra- 
tar todos os condenados execrandas penas por uma eternidade, e por isso temo muito ver falar de tal lugar.

M. Pois sabeis, senhor, que suposto seja a consideração do inferno tanto para temer e recear, também é proveitosa para muitas coisas. A primeira é, para sofrermos os trabalhos desta vida, como sofreram e suportaram os santos, que estão hoje gozando de bem aventurança por cuidarem dos horríveis tormentos que há no inferno. ${ }^{61}$

O diálogo estabelece assim a articulação entre os exemplos, alegorias e citaçóes no decorrer da obra, proporcionando o meio de expor ao pretendido leitor os caminhos para a salvação e a orientação para renúncia dos maus costumes. Este texto procurou mostrar como a análise dos costumes religiosos e as formas de se buscar a salvação são constituídas por formas pré-estabelecidas na tradição.

Nuno Marques Pereira dialoga gêneros e princípios formais de construção de texto que podem ser observados nos sermões de Vieira, nas cartas jesuíticas e outras obras que precederam o Compêndio narrativo do peregrino da América. Tratou-se de tentar mostrar como não se pode tomar a obra de Nuno Marques Pereira como documento que informa sobre a "realidade", na medida em que o autor constrói seu texto a partir de quadros temáticos e modelos formais pré-existentes que constróem uma representação "verossímil" da realidade. Ao se buscar realizar uma leitura por esta via de interpretação, tentou-se apenas trazer à tona a relevância da compreensão dos procedimentos formais de construção textual para um enfoque da obra de Nuno Marques Pereira, a qual traz à tona elementos significativos para se refletir acerca da literatura religiosa produzida no século XVIII. 


\section{Referências bibliográficas}

ALCIDES, Sérgio. Estes Penhascos. Cláudio Manuel da Costa e a paisagem das Minas, 1753-1773. São Paulo: Hucitec, 2003.

DRUMMOND, Maria Francelina. Brasil peregrino na alegoria de Nuno Marques Pereira. Tese de doutorado apresentada ao Programa de Pós-Graduação em Letras em Estudos Literários da Faculdade de Letras da UFMG. Belo Horizonte, 2000.

HANSEN, João Adolfo. Alegoria: construção e interpretação da metáfora. São Paulo: Atual, 1986.

HOLANDA, Sérgio Buarque de. Visão do Paraiso. São Paulo: Brasiliense, 1996. HOLANDA, Sérgio Buarque de.O ideal arcádico. In: Capitulos de literatura colonial. São Paulo: Brasiliense, 1991.

PEREIRA, Nuno Marques. Compêndio narrativo do peregrino da América (1728). Rio de Janeiro: Publicações da Academia Brasileira, 1939. v.2, 6 ed.

VILELA, Magno.Uma questão de igualdade: Antônio Vieira e a escravidão negra na Babia do século XVII. Rio de Janeiro: Relume Dumará, 1997.

SOUZA, Laura de Mello e. Inferno Atlântico: demonologia e colononização, séculos XVI-XVIII. São Paulo: Companhia das Letras, 1993.

SOUZA, Laura de Mello e. O diabo e a terra de Santa Cruz. Feitiçaria e religiosidade no Brasil Colonial. São Paulo: Companhia das Letras, 1986, pp. 144-145. VAINFAS, Ronaldo. Trópico dos pecados. Moral, sexualidade e inquisição no Brasil. Rio de Janeiro: Nova Fronteira, 1997.

\section{Notas}

${ }^{1}$ PEREIRA, Nuno Marques. Compêndio narrativo do peregrino da América (1728). 6 ed. Rio de Janeiro: Publicações da Academia Brasileira, 1939. 2 vol.

${ }^{2}$ Consta que a publicação da obra de Nuno Marques Pereira só foi possível mediante o apoio de Manoel Nunes Viana que teria custeado a sua impressão. A essa edição, seguiram-se outras quatro ediçôes no século XVIII, sugerindo a considerável aceitação da obra: 1731, 1752, 1760 e 1765. DRUMMOND, Maria Francelina. Brasil peregrino na alegoria de Nuno Marques Pereira. Tese de doutorado apresentada ao Programa de Pós-Graduação em Letras em Estudos Literários da Faculdade de Letras da UFMG. Belo Horizonte, 2000. ${ }^{3}$ Sobre a associação da obra de Nuno Marques Pereira com as reflexões demonizadoras acerca da América, ver: SOUZA, Laura de Mello e. Inferno Atlântico: demonologia e colo- 
nização, séculos XVI-XVIII. São Paulo: Companhia das Letras, 1993, particularmente o primeiro capítulo “O conjunto - América diabólica”, pp. 21-46.

${ }^{4}$ VARNHAGEN, O peregrino da América e o seu autor, natural de Cairú. Juízo crítico In: PEREIRA, Nuno Marques. Op.cit, p. IX.

${ }^{5}$ Sobre este aspecto, ver o estudo que prefacia a edição de 1939: VASCONCELOS, José Leite de. O "Peregrino da América" de Nuno Marques, como fonte de investigação etnográfica. In: PEREIRA, Nuno Marques. Op. cit, v.2, pp. XIX-XXIX.

${ }^{6}$ Sobre este aspecto, ver a observação acerca dos Calundus, rituais africanos exorcizados pelo Peregrino. SOUZA, Laura de Mello e. O diabo e a terra de Santa Cruz. Feitiçaria e religiosidade no Brasil Colonial. São Paulo: Companhia das Letras, 1986, pp. 144-145 e VAINFAS, Ronaldo. Trópico dos pecados. Moral, sexualidade e inquisição no Brasil. Rio de Janeiro: Nova Fronteira, 1997.

${ }^{7}$ PÉCORA, Alcir. Máquina de Gêneros. São Paulo: Edusp, 2001, p. 16.

${ }^{8}$ Ibidem, p. 14.

${ }^{9}$ PEREIRA, Nuno Marques. Op. cit, v. 2, p. 6.

${ }^{10}$ Ibidem, v. 2, p. 4

${ }^{11}$ Ibidem, p. 5.

${ }^{12}$ Sobre a importância do estilo humilde e da preocupação que tinha Vieira com o sentido das palavras ver: VILELA, Magno. Uma questão de igualdade: Antônio Vieira e a escravidão negra na Bahia do século XVII. Rio de Janeiro: Relume Dumará, 1997, pp. 66-67.

${ }^{13}$ PEREIRA, Nuno Marqeus. Op. cit, v. 2, p. 192

${ }^{14}$ Sermões, I, p. 49 Apud: PÉCORA, Alcir, op. cit, pp. 137-138.

${ }^{15}$ PEREIRA, Nuno Marques. Op. cit,v. 2, p. 57.

${ }^{16}$ PÉCORA, Alcir. Op. cit, p. 158.

${ }^{17}$ Em estudo dedicado a Cláudio Manoel da Costa, Sérgio Alcides chama atenção para a importância que assume em Portugal o que o autor denomina de "reforma do gosto", cujos principais esforços se viram congregados em torno da Arcádia Lusitana fundada em 1756. Para Alcides, a "reforma do gosto" congregava o ideal arcádico na projeção das virtudes dos autores da Antiguidade - a exemplo de Virgílio e Horácio -, o combate às influências espanholas calcado no classicismo francês, assumindo no Reino uma reação antijesuítica, antiescolástica e anticultista. Ségrio Alcides retoma aqui o problema analisado anteriormente por Sérgio Buarque de Holanda, o qual afirmava que o culto do "natural", ou seja, da razão e do bom senso, teve um aspecto epidérmico e exterior, convivendo aí o ideal arcádico com o cultismo da linguagem associado ao barroco. De certa forma, as contradições estruturais que se observam nas obras do século XVIII se refletem na obra de Nuno Marques Pereira. Ao mesmo tempo em que condena o cultismo e se refere a Horácio como condição de perfeição, o autor elogia Góngora e Quevedo. ALCIDES, Sérgio. Estes Penhascos. Cláudio Manuel da Costa e a paisagem das Minas, 1753-1773. São Paulo: Hucitec, 2003, pp. 35-76. HOLANDA, Sérgio Buarque de. O ideal arcádico. In: Capitulos de literatura colonial. São Paulo: Brasiliense, 1991, pp. 177-226. 
${ }^{18}$ PEREIRA, Nuno Marques.Op. cit,v. 2, p. 58.

${ }^{19}$ Ibidem, p. 58.

${ }^{20}$ Sobre a leitura do Compêndio narrativo do peregrino da América enquanto obra alegórica ver: HOLANDA, Sérgio Buarque de. Visão do Paraíso. São Paulo: Brasiliense, 1996, p. 174.

${ }^{21}$ PEREIRA, Nuno Marques. Op. cit, v. 1, p. 309.

22 Ibidem, p. 37.

${ }^{23}$ João Adolfo Hansen foi um dos autores que se dedicou ao estudo das questões referentes à alegoria. Segundo o autor, "não se pode falar simplesmente de $a$ alegoria, porque há duas: uma alegoria construtiva ou retórica, uma alegoria interpretativa e hermenêutica. Elas são complementares, podendo-se dizer que simetricamente inversas: como expressão, a alegoria dos poetas é uma maneira de falar; como interpretação, a alegoria dos teólogos é um modo de entender. HANSEN, João Adolfo. Alegoria: construção e interpretação da metáfora. São Paulo: Atual, 1986.

${ }^{24}$ De acordo com Maria Francelina Drummond, a admiração que o "peregrino" demonstra por Orígenes contribui para que se compreenda os usos da alegoria no Compêndio narrativo..." Orígenes precede e forma uma longa tradição exegética que utiliza o método alegórico para interpretação da Bíblia" que será utilizado por Santo Agostinho, São Gerônimo, entre outros que dialogo Nuno Marques Pereira. DRUMMOND, Maria Francelina. Op. cit., p. 141.

${ }^{25}$ ALCÍDES, Sérgio. Op.cit., p. 82.

${ }^{26}$ Conforme afirma José Antônio Maravall, "o que interessa ao escritor barroco enquanto tal é revelar o esquema irredutível desse curso temporal: sua fugacidade. MARAVALL, José Antonio. A cultura do Barroco: análise de uma estrutura histórica. São Paulo: Edusp, 1997, p. 301.

${ }^{27}$ PEREIRA, Nuno Marques. Op. cit., v. 1, p. 309.

${ }^{28}$ Estudo clássico sobre o tema é o de HOLANDA, Sérgio Buarque. Visão do Paraíso. São Paulo: Brasiliense, 1986. O tema foi retomado em parte por SOUZA, Laura de Mello e. O Diabo e a Terra de Santa Cruz. Feitiçaria e religiosidade popular no Brasil colonial. Op. cit., pp. 21-49.

${ }^{29}$ PEREIRA, Nuno Marques. Op. cit., v.2, p. 25.

${ }^{30}$ Ibidem, p. 26.

${ }^{31}$ Ibidem, p. 30.

32 Sobre o tema da natureza e dos maus costumes nas cartas jesuíticas ver: PÉCORA, $O p$. cit., pp. 40-46.

${ }^{33}$ Ibidem, v. 2, p. 240.

${ }^{34}$ Ibidem, p. 227.

${ }^{35}$ HANSEN, João Adolfo. Op. cit., p. 99.

${ }^{36}$ PEREIRA, Nuno Marques. Op. cit., v. 1, p. 317.

${ }^{37}$ Ibidem, pp. 320-321. 
${ }^{38}$ Ibidem, v. 2, p. 102.

${ }^{39}$ Ibidem, p. 106.

${ }^{40}$ Ibidem, pp. 137-138.

${ }^{41} \mathrm{O}$ primado da visão sobre os outros sentidos é afirmado por vários autores religiosos. Santo Inácio de Loyola, já no primeiro “exercício espiritual”, requeria dos penitentes uma representação concreta de uma imagem através da imaginação (imagem das chagas de Cristo, por exemplo), ou seja, "la composicion viendo el lugar". O Padre Antonio Vieira em seus "Sermóes" afirmava que "o que entra pelos ouvidos, como tem menos evidência, move com menos força; mas o que entra pelos olhos, recebe a eficácia da mesma vista e move fortissimamente”. Sto Inácio de LOYOLA. Op. cit. p. 82; Pe. Antonio VIEIRA. Sermoens XV. p. 66. APUD: HOLANDA, Segio Buarque de. Visão do Paraíso. São Paulo: Brasiliense, 1996, p. 232.

42 PEREIRA, Nuno Marques. Op. cit., p. 138.

${ }^{43}$ DRUMMOND, Maria Francelina. Op. cit., pp. 66-67.

${ }^{44}$ Ibidem, v.2, pp. 261-262.

${ }^{45}$ Ibidem,v1, pp. 318-319.

${ }^{46}$ Ibidem, v. 2, p. 202.

${ }^{47}$ Ibidem, p. 70.

${ }^{48}$ Sobre o procedimento de citação "indireta" em Nuno Marques Pereira, ver: DRUMMOND, Maria Francelina. Op. cit., p. 145.

${ }^{49}$ Ibidem, v. 1 ,p. 315.

${ }^{50}$ Ibidem, p. 315.

${ }^{51}$ Ibidem, v. 2, p. 81.

52 Para essas informações sobre o gênero do diálogo, ver: PÉCORA, Alcir. Op. cit., p. 97.

${ }^{53}$ Sobre os livros que influenciaram a forma dialógica adotada por Nuno Marques Pereira, ver: DRUMMOND, Maria Francelina. Op. cit., pp. 143-144.

54 PEREIRA, Nuno Marques. Op. cit.,v. 2, p. 77.

55 Ibidem, v. 1, p. 433.

${ }^{56}$ Ibidem, p. 435.

${ }^{57}$ Ibidem, v. 2 p. 207.

${ }^{58}$ Conforme afirma Alcir Pécora, "o diálogo pode ser retoricamente definido como gênero que compõe diferentes discursos a partir do relato de uma cena dramática mínima que pressupóe a presença simultânea de personagens com distintas posições intelectuais, convivendo em uma determinada situação que exige a prática racional.” PÉCORA, Alcir. Op. cit., p. 98.

${ }^{59}$ Ibidem, p. 98.

${ }^{60}$ Ibidem, Op. cit., p. 97.

${ }^{61}$ PEREIRA, Nuno Marques.Op. cit., v. 2, p. 258. 


\section{Resumo}

A obra de Nuno Marques Pereira, Compêndio narrativo do peregrino da América, publicada em 1728, pertence ao vasto repertório da literatura de cunho moralizante produzida entre os séculos XVI e XVIII. Trata-se da narrativa de viagem que um suposto "peregrino" faz da Baía de Todos os Santos à Capitania das Minas, na qual discorre sobre os costumes religiosos no Brasil e aborda temas diversos, analisados à luz de uma teologia moral. Este artigo propõe analisar como Nuno Marques Pereira articula elementos discursivos disponíveis na tradição, como é o caso da alegoria e do diálogo, e o exame dos costumes e das práticas religiosas que observa na sociedade da América Portuguesa no século XVIII, que atuam como elementos decisivos na construção do texto.

Palavras-chave: Alegoria, teologia moral, práticas religiosas.

\section{Abstract}

The Work of Nuno Marques Pereira, Compêndio narrativo do peregrino da América, published in 1728, belongs to a vast repertoire of the literature of morality produced between the sixteenth and sevententh centuries. His Works deal with the voyage narrative that a supposed "pilgrim" takes from Baía de Todos os Santos to the Minas, and discusses the religious customs in Brazil and approach to different themes analyzed in the light of a moral theology. This article proposes an analysis of how Nuno Marques Pereira works with discoursive elements present in tradition, such as the allegory of the dialogue, as well as the analysis of the custom and religious practices observed in the American Portuguese society of the eighteenth century, which act as fundamental elements in the construction of the text. Key Words: Allegory, moral theology, religious practices. 